\title{
Supreme Audit Institutions and public value: demonstrating relevance
}

\author{
Carolyn Cordery,* David Hay** \\ * Victoria Business School, Victoria University of Wellington, P O Box 600 \\ Wellington \\ ** University of Auckland Business School, P O Box 92019 Auckland. \\ Corresponding Author: Carolyn Cordery, School of Accounting and Commercial Law, \\ Victoria Business School. E: Carolyn.cordery@ vuw.ac.nz; T: +644 4635761.
}

\begin{abstract}
:
Supreme Audit Institutions (SAIs) have an important role in ensuring public sector accountability; their main activities being managing the audit of public sector entities' financial statements and assessing probity/compliance, providing advice to parliamentary committees, and undertaking performance audits. Standards issued by the International Organisation of SAIs encourage SAIs to recognise the value they deliver through their activities and to demonstrate that to citizens, Parliament and other stakeholders. The recognition of the need to be democratically accountable for efficiency and effectiveness is one aspect of public value, which is also concerned with the just use of authority (Moore, 2013).

The purpose of this paper is to develop the components of a SAI's public value and, through a comparative international study, to analyse how SAIs report on the public value they deliver. Analysing reporting against the model developed in this paper indicates that SAIs' reporting prioritises critiques to increase public sector efficiency and effectiveness, rather than government policy. In addition, it finds SAIs generally fail to discuss any negative consequences of their work. SAIs are encouraged to develop new ways to demonstrate their ongoing relevance.
\end{abstract}




\section{Supreme Audit Institutions and public value: demonstrating relevance}

\section{Introduction}

Almost 200 countries around the world operate Supreme Audit Institutions (SAIs) These publicly-funded SAIs undertake financial statement audits for agencies and government as a whole, as well as compliance and performance audits (The World Bank, 2001). SAIs are ubiquitous, with the International Organization of Supreme Audit Institutions (INTOSAI) (2013) asserting that SAIs deliver public value through ensuring public sector accountability, and independently and objectively supporting reform. Thus, SAIs are challenged to report on to whom and how they deliver public value (Bringselius, 2014). The question of how SAIs demonstrate relevance is therefore worthy of further investigation.

Public value is increasingly important from a practical and theoretical point of view (Bryson, Crosby, \& Bloomberg, 2015), although it is widely recognised as a complex concept (Hartley, Alford, \& Hughes, 2015; Moore, 2013). Building on the principle of democratic accountability to citizens collectively, Moore (2014) argues that public value is concerned with the utilitarian ideal of efficiency and effectiveness of public resources to achieve outcomes, as well as the deontological aims seeking the appropriate use of authority to ensure a just and fair society. Moore's (2013, 2015) 'public value triangle' includes three aspects of public value, being: (i) an entity's strategy to deliver public value; (ii) its ability to attract legitimacy and support; and (iii) the operational feasibility of it delivering public value. Moore's $(1995,2015)$ narrative examples of public value has been augmented by others, yet empirical research into public value is scarce (Hartley, Alford, Knies, \& Douglas, 2016). Specifically, there are calls to further build public value theory through analysis of the processes that add value, and those that bring strategic change in the collective environment (Bryson, Sancino, Benington, \& Sørensen, 2016; Geuijen, Moore, Cederquist, Ronning, \& van Twist, 2016; Hartley et al., 2016). Further, although Moore (2013, 2015) develops a 'public value account', the role of entities' annual publications (annual report, annual plan, etc.) has not been explored. 
This research responds to gaps in the literature (as further described below), by developing a framework to map public value (as called for by, for example, Hartley et al., 2016) within SAIs. The contributions are threefold. This framework considers public value as an organisation-wide issue and utilises SAIs' accounting-related publications in reporting that value. This is in contrast to research that has analysed individual managers' responses to public value (Moore, 1995, 2013). Secondly, applying a public value framework to SAIs provides insights into how they report on the impact of their statutory audits which invoke agency theory and are used in the public sector to enhance organisational control and manage public risk (Hay, Simpkins, \& Cordery, 2016). ${ }^{1}$ SAIs are 'watchdogs of public value' (Moore \& Gates, 1987), and therefore we argue that SAIs should lead by example. Thirdly, we undertake a comparative international analysis of public value which recognises the contestability of SAIs' core strategies (including 'ensuring public sector accountability') (Moore \& Gates, 1987). The international framework we utilise establishes a set of 'best practices' but it also recognises the necessity of public input to develop agreed concepts of public value.

The paper first presents an analysis of public value, developing the model for the empirical research. The research method is discussed in section 3 , followed by the results. The paper concludes with a discussion, limitations and opportunities for further research.

\section{Public Value}

Since the NPM${ }^{2}$ reforms, the public sector has increased its focus on accountability, but also on: customers, performance measurement and management systems such as total quality management, cost improvements and pay-for-performance (Burgess \& Ratto, 2003; Moore, 1995; G. Scott, Bushnell, \& Sallee, 1990). Thus, an emerging literature considers public value (Bryson et al., 2015). Public entities are expected by various stakeholders to meet a number of goals, including the effective and efficient delivery of social outcomes, fairness and justice (Moore, 1995; G. Scott et al., 1990). A rational management approach requires entities to report against specific targets linked to the

\footnotetext{
1 Talbot and Wiggan (2010) analysed the public value delivered by the UK National Audit Office's Value for Money (VfM) (performance) audits. In contrast, we consider the range of audits undertaken by SAIs - both financial and performance audits.

2 New Public Management.
} 
objectives for which they are held accountable (Christensen, Lægreid, Roness, \& Røvik, 2007) to show they are efficient and effective. Nevertheless, measurement difficulties have led to inadequate reporting of qualitative impacts and vague outcome measures that do not assist in discharging accountability (Kloot, 2009; Lee, 2008; Moore, 2013; Pallot, 2003). ${ }^{3}$

To ascertain the value they deliver, public entities often measure customer (or stakeholder) satisfaction (G. Scott et al., 1990). Yet, such surveys may not adequately reflect issues of justice and fairness in society, such as whose utility is to be maximised, or the effect of public policy on those stakeholders (Moore, 1995, 2014). Instead, Moore (2013) argues for sustained and detailed discussions with citizens about what value is - highlighting that value is not merely represented by service quality (to individuals), but by performance against specific outcomes (affecting citizens in general). While citizens are essential to develop the constructs of public value, it is public managers who measure and ascertain the boundaries of public value (Bryson et al., 2015). Public agencies must also collaborate to deliver value (Bryson et al., 2016; Crosby, Hart, \& Torfing, 2016; Geuijen et al., 2016).

Bryson et al. (2015) note that definitions of public value (other than Moore's) exist. For example, Bozeman (2007) argues against the neo-liberal values in NPM and focuses not only on citizens' rights, but also citizens' obligations to society, and principles which should drive government policy-making. He analyses success and failure in respect of policy-making (Bozeman, 2007). Alternatively, Meynhardt (2015, p. 147) notes public value may "be seen as a way to contextualize financial and non-financial performance within a larger picture of human values established in the public sphere and in society at large". While this is similar to Moore, Meynhardt's (2015, p.147) public value is assessed at the individual or project level, rather than for an organization overall. In contrast, this study focuses on the public value that organisations (specifically SAIs) deliver and report on, rather than assessing that reported by individuals.

3 Other tools, for example adding contestability or establishing a quasi-market, are NPM methods used to increase utilitarian values of efficiency in public value (Pallot, 2003), although they are not necessarily extendable to meeting deontological aims for fairness and justice. 
As noted above, Moore (1995, 2013) suggests public entities can build public value through a 'strategic triangle'. Thus, public value is not delivered and reported on as a single concept, but as a combination of each of the triangle's aspects so that learning and development occur to deliver public value (Moore, 2013). In this paper, we develop a framework of SAI reporting that considers each of these strategic points (see subsections below). To do this, we utilise literature and the International Standard for SAIs (ISSAI) 12: The Value and Benefits of Supreme Audit Institutions - making a difference to the lives of citizens (INTOSAI, 2013), which requires SAIs to "demonstrate their ongoing relevance to citizens, Parliament and other stakeholders". As these stakeholders fund SAIs, we suggest this relevance is delivered by the extent to which SAIs report on the public value they deliver.

\subsection{A strategy to develop public value}

Two aspects of public value are analysed: the need for public sector accountability and the role of SAIs in independently and objectively supporting reform (INTOSAI, 2013). Moore (2013, p. 86) notes that, in addition to elected representation “... the threat of audits create[s] a powerful, continuous current of accountability that runs through public agencies". ${ }^{4}$ It is axiomatic that public sector accountability is a key outcome of an SAI's public value. Indeed, the Open Budget Survey 2015 (International Budget Partnership, 2015 (IBP)) states that countries with strong formal oversight systems (i.e. SAIs), budget transparency and public participation, will have efficient, effective and accountable budget systems. "Audits are a vital part of the checks and balances on the governmental budgetary process", preventing fraud and waste, and checking probity and legality (Friedberg \& Lutrin, 2005, p. 4).

Operationally, an independent SAI's role "is to scrutinize the use of public funds, diagnose potential problems, and propose solutions" (IBP, 2015, p. 51). Such public value was confirmed in a Mexican citizen survey, as $77 \%$ of respondents agreed it was important for public institutions to be held accountable and act with transparency, ${ }^{5}$ more than two-thirds stated the SAI's recommendations had helped to improve government

\footnotetext{
4 Yet, he also notes that "the daily swirl of democratic politics is both powerful and problematic" leading to demands from interest groups, citizens and the media (Moore, 2013, p. 88).

5 Further, $83 \%$ of specialists (MPs, auditees and the media) were more emphatic agreeing accountability was "very important".
} 
processes, and $75 \%$ agreed that the SAI collaborated in the fight against corruption (González de Aragŏn, 2009).

The vast majority of countries use SAIs for audit (with a small minority using internal auditors only) (OECD, 2000). Confirmation of the value of these checks can be seen in various US State legislatures requiring performance audits, including in Ohio where the citizens voted to apply a percentage of State Sales tax to funding such audits (Raaum \& Campbell, 2006; Schultz \& Brown, 2003). However, even though Blume and Voigt (2011) argue that effective SAIs should be able to reduce corruption compared to countries where SAIs are not effective, this was not borne out in their study utilising the Corruption Perception Index from Transparency International. It showed that the structure of the SAI (whether it uses the Napoleonic or court model) was the only measure that had significant explanatory power (Blume \& Voigt, 2011). ${ }^{6}$ Nevertheless, when SAIs report on corruption it can be useful. For example, Bangladesh's SAI has a role in assuring foreign aid and debt providers as to the efficacy of government accounts (Chowdhury, Innes, \& Kouhy, 2005).

It is difficult to find an objective measure of how SAIs increase public sector accountability, with Wilkins (1995, p. 429) suggesting surrogate measures such as rating by the auditee and "other relevant third-party observers of the audit offices' contribution to public sector accountability". SAIs must assist Parliamentary oversight committees to take appropriate action through high quality reporting and by building their scrutinising capacity (INTOSAI, 2013; Santiso, 2015).

Under agency theory, audit recommendations/reports are one way to ensure public sector accountability. In Norway, Reichborn-Kjennerud and Johnson (2015) found that performance audit recommendations were more likely to be positively responded to, if they are used as: (i) Parliamentary measures of auditees, (ii) tools to hold Ministers accountable to Parliament, ${ }^{7}$ and (iii) methods to improve organisational systems by auditees who believe them to be useful. Vanlandingham (2011) also found in the US that, when States have legislative requirements for evaluators and auditors to include recommendations in reports, auditees are more likely to implement them (than in those

\footnotetext{
6 Many of the measures used by Blume and Voigt (2011) such as tax rates and economic growth are influenced by many other factors as well as auditing. Further research using this approach is likely to be worthwhile.

7 Both of these also occur in Israel (Alon, 2007; Milgrom \& Schwartz, 2008).
} 
States where no such legislation exists). ${ }^{8}$ Such accountability pressures are the largest drivers of change, which is an important demonstration of audit effectiveness (Reichborn-Kjennerud \& Johnsen, 2015).

SAIs must be "a credible source of independent and objective insight and guidance to support beneficial change in the public sector" (INTOSAI, 2013, p. 9). The most obvious examples of SAIs independently and objectively supporting reform are their performance audits. These aim to improve public sector management (Arthur, Rydland, \& Amundsen, 2012), with SAIs commonly reporting on how many of their recommendations are accepted and acted upon (Gendron, Cooper, \& Townley, 2001; INTOSAI, 2013, s. 3.6). Yet, Raudla et al. (2015) found in their Estonian study, that fewer than $10 \%$ of the auditees they surveyed considered performance audits as being engagements to hold them accountable for their actions. This could be due to a prioritisation of learning (a cultural-institutional perspective), rather than the strict accountability (a rational-instrumental perspective) (Christensen et al., 2007; Raudla et al., 2015; Reichborn-Kjennerud \& Johnsen, 2015). Indeed, SAIs' relationships with auditees are frequently non-hierarchical and such recommendations require negotiation and compromise (C. Scott, 2003). ${ }^{9}$ Thus, Reichborn-Kjennerud and Johnson (2015) explain that the Norwegian SAI's performance audits are effective when the auditees have previously planned to make the recommended changes. ${ }^{10}$ This result is similar to the Dutch audits studied by Van Der Meer (1999). Nevertheless, Reichborn-Kjennerud and Johnson (2015) did not find support for the other cultural-institutional perspective factor, which was that auditees' changes would be more dramatic depending on their agreement with the SAI's recommendations. Yet, the Dutch study by De Vries reported in Van Loocke and Put (2011) found that changes were more likely to occur when auditors and auditees shared similar ideas, as also suggested by Vanlandingham (2011).

8 In 2009, the IBP found that 17 countries had no follow-up of recommendations, there was minimal follow-up in 20 countries and in 64 countries "the executive did not reveal what steps, if any, it had taken to address audit recommendations" (Ramkumar, 2009, p. 12).

9 Etverk (2002) found that, due to the relative newness of performance auditing in that country, auditees were less familiar with SAI staff being 'consultants' (who would try to influence auditees by persuasion and discussion), and yet viewed these performance auditors more positively than traditional auditors who were perceived as 'watchdogs'.

10 Nonetheless, Raudla et al. (2015) suggest that when the auditees are aware of the challenges, they may have already put measures in place to correct them and that this may lead to no further changes being made (and thus reduce the value they place on the audit). This shows the complexity of measuring auditees' perceptions of the change catalyst. 
Tracking and publishing auditees' implementations of SAIs' recommendations therefore appears to be a measure of public value, but of the 29 SAIs for which Blume and Voigt (2011) had monitoring data, only 14 did so fully (11 had a partial tracking system/did not publish the data). However, examples from the UK and the Netherlands report 'success rates' for recommendations of between $67 \%$ within three years and 90 100\% overall, Australia has 91\% and the US from 72-83\% (Azuma, 2004; Lonsdale, 2000). ${ }^{11}$ Yet, Raudla et al.'s (2015) Estonian study of auditees found only $21 \%$ agreed that a performance audit had led to their organisation adopting recommended changes, although $40 \%$ believed the performance audit had been useful.

Morin (2001) argues that tracking the acceptance of recommendations is a simplistic measure of an audit's success. Her multi-measure schema for performance audits includes 14 performance indicators and 11 factors based on a number of behavioural factors: the perceptions and reaction of the auditees, the impacts of the performance audit, and the extent of public debate arising from the public report. Morin (2008) finds the actions of the Public Accounts Committee and the media enhances the effect of the audit report, as did Etverk's(2002) similar Estonian study. However, if popularity with auditees is a prime measure, an SAI's independence and accountability could be impaired (Noussi, 2012).

The public auditor's role is changing, as shown by Gendron et al.'s (2001) study of two decades of reports from the Office of the Auditor General of Alberta (OAGA). They find that the OAGA is now more likely (than in the past) to identify opportunities and propose solutions, to offer help to auditees, use dramatic examples for benchmarking (including drawing on international examples), and congratulate public servants and government (Gendron et al., 2001). These persuasive and influencing tactics show that public auditors have become 'problem solvers' (Gendron et al., 2001). Morin's (2008) study of Quebec performance auditors also finds they are more likely to initiate change than not, although Morin's (2014) survey of the impact of ten years of performance

11 Context will be important. For example, Hasan et al. (2013) describe a continuous improvement rating scheme in UK local authorities, which was rated under Audit Commission principles (by the Audit Commission or a private sector auditor) and led to many changes to meet "best practice". However, Hatherly and Parker (1988) suggest that State Auditors-General had less success with Australian local authority audit recommendations. 
audit in Canada (2001-2011) logged a mean score on a seven-point Likert scale of 3.5/7 for "improvement of management", which shows that change is not always positive.

While auditee feedback is a measure of 'client satisfaction' and therefore part of the public value chain (Moore, 2013), a further measure of public value (beyond that to individuals) is for SAIs to contribute internationally (INTOSAI, 2013 s. 1.2, $7.3 \&$ 7.5). Noussi's (2012) study shows that high-performing SAIs with strong regional influence encourage other SAIs within the region to also implement reforms. Such a correlation suggests that the operational capacity and legitimacy and support within SAIs internationally will contribute to their ability to deliver public value.

\subsection{Legitimacy and Support}

SAIs can obtain legitimacy and support through being independent and trustworthy. To ensure external audits are credible and meaningful, independence from government as executive is critical (Barrett, 1996; Pollitt \& Summa, 1997). Independence sustains a SAI when it has appropriate processes (i.e. freedom to choose what to audit and when, what to publish) (Grasso \& Sharkansky, 2001; INTOSAI, 2013, ppl 1), and appropriate institutional arrangements (i.e. constitutional or legislative independence, a process for guaranteed funding, control over staff). In particular, using data from US state auditors, Schelker (2008) finds a positive correlation between the independence of auditor appointment (i.e. whether appointed by the legislature or elected by citizens), and the legislature's audited financial statement quality.

While Normanton (1966) states that auditors risk their independence by reviewing public policy, some argue that the principle is breached when SAIs undertake performance audits to evaluate the substance of programmes (Barzelay, 1997; Gendron et al., 2001; Grasso \& Sharkansky, 2001). For example, Grasso and Sharkansky (2001), in their analysis of SAIs in the US and Israel, suggest growing pressure for SAIs to deal with politically sensitive issues (such as policy debates). From Germany, CzascheMeseke (1995) notes that it is a 'fine line', and unavoidable that sometimes the most carefully worded reports become caught in the political cross-fire. ${ }^{12}$ Indeed, Grasso and

12 Mulgan's (2001, p. 25) analysis of Australian Auditors-General finds that "open clashes with government, however, are exceptions rather than the rule", with confrontations limited mainly to matters of process and probity, as opposed to efficiency and effectiveness. Barrett (2002) notes it is a particular challenge and occurs when policy and implementation are difficult to separate. When his Office undertook performance audits on property sales and IT outsourcing, they elicited 'significant 
Sharkansky (2001, p. 1) argue that the purist conception of independence is obsolete and that objectivity is required instead, with it being "more realistic to urge diligence on the part of the supreme auditor". This is evident in Jantz et al.'s (2015) analysis of performance reports from SAIs in Denmark (6 reports), Norway (6 reports) and Germany (7 reports), as only one criticised policy. SAIs' unwillingness/ inability to critique policy reduces the likelihood that they will contribute to the deontological aims for fairness and justice, but instead prioritise utilitarian efficiency and effectiveness.

SAIs need funding to operate. While some believe auditees should co-fund audits, many others argue SAI funding should be a core government appropriation (Lovell, 1996). If corrupt entities fund the auditor and no safeguards exist, audit quality may reduce due to pressure from the corrupt auditee, as found by Liu and Lin's (2012) study of Chinese regional public sector audits. Even with State funding the same pressure applies, with Melo et al.'s (2009) Brazilian study finding that State Auditors with larger budgets were less likely to reject the (funding) legislature's accounts.

The SAI must be trusted if it is to retain legitimacy with and support from its auditees and other stakeholders (Talbot \& Wiggan, 2010). This includes SAIs subjecting themselves to external scrutiny (INTOSAI, 2013 s. 8.5): such as commissioning an audit of their own reports (Wilkins, 1995), meeting quality councils' accreditation requirements and subjecting themselves to independent review (Barrett, 1996). Yet, in many countries, the fear of impaired independence means SAIs are not statutorily required to be subjected to performance audit themselves (Clark, De Martinis, \& Krambia-Kapardis, 2007; Funnell, 2015). Under agency theory, such audits could be expected to increase confidence (and therefore trust) in those who cannot observe SAIs' activity directly (Lovell, 1996; Streim, 1994). Further, James and John (2007) find in UK local government, that voters trusted the Audit Commission's performance measurement more than politicians' statements. $^{13}$ In respect of the signalling

comment' (Barrett, 2002). In her analysis of PPP audits in Australia, English (2007) distinguishes between system-based audits and substantive audits that critique the effectiveness of policy implementation. These latter are infrequently undertaken, with English (2007) noting they may not only impair the public auditor's independence, but that also the auditor may find it difficult to access and/or report on confidential information relating to PPP contracts. This was also a concern in the UK when the NAO undertook performance audits of entities for which it did not audit the financial statements (Bowerman, Humphrey, \& Owen, 2003).

13 Yet, Melo et al. (2009) find that political competition is positively correlated to audit activity, suggesting that the more power a government has, the less audit and accountability discharge there 
explanation for audit, Schelker's (2008) study of US state auditors find that the more trustworthy the auditor, the less likely voters will elect a divided State government, believing the auditor will act as a control (which an otherwise active opposition would wield).

Independent measures of this trust are lacking. The OECD (2013) uses data asking about specific aspects of government, but, as it does not focus on SAIs, it is difficult to measure whether trust in a SAI increases trust in government, or if cultural or political issues are stronger (OECD, 2013). Nevertheless, confidence in government is negatively correlated to the perception of government corruption (OECD, 2013) - an issue that SAIs can impact. To be trustworthy, SAIs also need exemplary operational capacity.

\subsection{Operating Capacity}

Moore's (2013) third point of the strategic triangle is operating capacity. Operating capacity enables SAIs to deliver public value through high quality audits and responding appropriately to stakeholders. To ensure public sector accountability, an SAI must "be a model organisation through leading by example" (INTOSAI, 2013 ppl 9) and, in effect, applying the same criteria to itself as it does to its auditees (Pollitt \& Summa, 1997). This includes using legitimate audit standards, maintaining currency with audit techniques, complying with codes of ethics and having well-trained staff (INTOSAI, 2013 ppl 8-12). The European Court of Audit's (ECA) work and reports have been criticised for not leading by example (Groenendijk, 2004) and, in a report on the IBS 2009 Open Budget Survey, Ramkumar (2009) finds that 27 out of 85 surveyed SAIs do not make audit reports publicly available, and six do not produce audit reports at all. This is despite ISSAI 12 (INTOSAI, 2013 s. 2.4, $3.2 \&$ ppl 4) emphasising the need for SAIs to report audit results.

SAIs are expected to be efficient (INTOSAI, 2013 s. 8.4), as shown in Melo et al.'s (2009) Brazilian study where efficiency is positively correlated to budget size and the presence of an independent career auditor (as opposed to a political crony). Further, Azuma (2004) notes that SAIs lead by example when they publish annual reports and annual plans, outline the outcomes they are working towards and outputs they have

is. However, because Brazil is a relatively new democracy, they also find that where there is low institutionalization, vote volatility is negatively related to audit activity. 
produced. Talbot and Wiggan (2010) argue audits are more robust and valuable when they include new techniques such as service user surveys, focus groups and outside interest groups. For example, the Norwegian Parliament expects that country's SAI's performance audits to examine whether users are satisfied with government services (Arthur et al., 2012).

As public value is assessed by citizens (Moore, 2013), another aspect of SAIs' operating capacity is facilitating communication with citizens (INTOSAI, 2013 s. 6.4). This includes maximising media coverage, especially as, notes Dye (2009, p. 8), "Parliamentarians around the world, tend to be media junkies". Nevertheless, Raudla et al. (2015, p. 14) suggests that media attention by itself does not lead to change in auditees, but that the media's role becomes significant when it leads to "political debate and increased pressure from the opposition". Further, while developing relationships with media could impair SAIs' independence, Bringselius' (2014) Swedish example shows that such relationships are necessary when there is no statutory requirement for Parliament to respond to audit reports. Hence, to measure public value, an SAI could measure the number of media releases, or the amount of media activity following audits (Bringselius, 2014; Lonsdale, 2000). Nevertheless, the Effective Institutions Platform (2014) reports SAIs generally do not evaluate the value stakeholders place on SAIs' work.

To deliver public value, SAIs should not wait for Parliament to take action, but report clearly and simply to all stakeholders, increasing stakeholders' knowledge of accountability in the public sector and the SAI's role in this (INTOSAI, $2013 \mathrm{ppl} 4 \&$ 6). This may include, for example, publishing annual audit plans, undertaking surveys, maintaining a website, and using social media (Effective Institutions Platform, 2014; United Nations Department of Economic and Social Affairs, 2013) to develop a twoway dialogue so that SAIs work on matters relevant to stakeholders. Stakeholders will not want to engage if the matters are irrelevant (Moore, 2013). Indeed, Brown and Craft's (1980) US study find that the most effective performance audits are those that were on a subject of interest to the public and press, but also have material findings and were well-timed.

Participatory mechanisms must also be representative (Effective Institutions Platform, 2014), otherwise the SAI will receive poor signals about potential fraud or 
inefficiencies (and, as noted by Bryson et al., 2015, may be biased). The IBS (2015) survey found that 31 SAIs do have mechanisms for public complaints which could feed through to audit topics. Yet, the IBS's 2009 Open Budget Survey finds that: (i) 12 out of 46 countries did not have mechanisms for the public to recommend potential subjects for audit; and (ii) 44 surveyed SAIs did not include an executive summary in their audit reports, making audit reports hard to read (Ramkumar, 2009).

With open data becoming more common and available, the concept of the "armchair auditor" suggests citizens may choose data (via various technological means) and analyse it as they see fit (O'Leary, 2015). These citizens may, for example, act as a control on government overspending if they communicate with the SAI or publish a report. Nevertheless, barriers include poor access to data, methodologies and analysing structures, missing data, and no clear community of "armchair auditors" which may lead to uninformed or malicious attacks on public sector entities (O’Leary, 2015).

International literature suggests SAIs' business-as-usual financial and performance audits can be measured as public value as shown in Table 1. This table also suggests unintended negative impacts could eventuate when entities are attempting to deliver public value (Moore, 2013). 
Table 1: Measuring public value in SAIs - a summary

\begin{tabular}{|c|c|c|c|}
\hline $\begin{array}{l}\text { Moore's } \\
\text { strategy }\end{array}$ & $\begin{array}{l}\text { ISSAI principle/s and } \\
\text { description }\end{array}$ & Positive Impact measured by: & Negative Impact of measurement: \\
\hline \multirow{2}{*}{$\begin{array}{l}2 . \\
\text { Legitimacy } \\
\text { and } \\
\text { Support }\end{array}$} & SAI Independence & $\begin{array}{l}\text { Independence measured by assessing legislative and other arrangements } \\
\text { (for example, Blume \& Voigt, 2011; Robertson, 2013). No impact found. }\end{array}$ & $\begin{array}{l}\text { Melo et al. (2009) suggest a large budget } \\
\text { could impair independence. }\end{array}$ \\
\hline & Building trust & $\begin{array}{l}\text { Accreditation, reviews by PAC and other external bodies, providing } \\
\text { summary measures (Barrett, 1996; James \& John, 2007) }\end{array}$ & $\begin{array}{l}\text { May reduce diversity of Parliamentary } \\
\text { Representation (at local level) (James \& } \\
\text { John, 2007; Schelker, 2008). }\end{array}$ \\
\hline $\begin{array}{l}3 . \\
\text { Operating } \\
\text { Capacity }\end{array}$ & $\begin{array}{l}\text { Responsiveness and } \\
\text { voice }\end{array}$ & $\begin{array}{l}\text { Number of media releases/media activity following audits (Raudla et al., } \\
\text { 2015); } \\
\text { Extent of public debate (Bringselius, 2014; Etverk, 2002; Morin, 2001) } \\
\text { and input to audit activity; } \\
\text { Number of public complaints and how they have been dealt with } \\
\text { (Effective Institutions Platform, 2014). }\end{array}$ & $\begin{array}{l}\text { Relationship with media may impair } \\
\text { independence; Input from stakeholders } \\
\text { may not be representative (Effective } \\
\text { Institutions Platform, 2014; O’Leary, } \\
\text { 2015). }\end{array}$ \\
\hline
\end{tabular}




\section{Method}

The organisational framework developed in the prior section uses audit literature, Moore's concept of public value and ISSAI 12 (INTOSAI, 2013). While disparate literature has analysed some aspects of this value, this research undertakes a comparative international study empirically analysing SAI reporting on the public value they deliver and through which they demonstrate their relevance. First, a list of all country members of INTOSAI was extracted ${ }^{14}$ and an internet search was undertaken of each SAI for documents using the term/s: "Public value", "Value of audit", "Benefits", "Making a difference", "ISSAI 12", and "ISSAI". Relevant documents were downloaded and content analysis was undertaken by coding against the normative model (NViVO was used to store the manual codings). Table 2 shows the results of the website search.

Table 2: Countries with SAIs included in this research

\begin{tabular}{|l|r|}
\hline SAI categories & No. \\
\hline $\begin{array}{l}\text { Number of countries' SAIs searched for } \\
\text { Number of SAIs without a website or where the website was not available }\end{array}$ & $(49)$ \\
\hline Total websites searched & $\mathbf{1 4 3}$ \\
\hline $\begin{array}{l}\text { Number of websites without a search facility (or needing an authorised log- } \\
\text { in to search) }\end{array}$ & $(35)$ \\
\hline \begin{tabular}{l} 
Number of websites where information is not in English \\
\hline Sub-total
\end{tabular} & $\mathbf{7 3})$ \\
\hline $\begin{array}{l}\text { SAI websites without information on the search terms, where information } \\
\text { was irrelevant to enquiry, or where reports sought were not in English }\end{array}$ & $\mathbf{7 5 7}$ \\
\hline Total number of countries whose SAIs' annual reports, strategic plans \\
and annual plans were analysed.* & $\mathbf{1 6}$ \\
\hline
\end{tabular}

*These countries were: Australia, Bangladesh, Canada, Estonia, Hungary, Iceland, Ireland, Jamaica, New Zealand, Norway, Poland, South Africa, Switzerland, Turkey, the UK, and US.

In terms of Azuma's (2004) recommendation that SAIs produce a Strategic Plan, Annual Plan and Annual Report, the selected SAIs' websites were further searched for

14 The full list can be found here: http://www.intosai.org/about-us/organisation/membership-list.html. Regional bodies (such as ECA, EUROSAI, PASAI, AFROSAI) are not included in this analysis. 
these documents as the basis of the analysis. In some cases (e.g. Norway, Switzerland) the output in English was a summary of the documents in the official language. As we were limited to English, this limited our analysis. In addition to positive values, we also sought to analyse any challenges SAIs face and how they have responded to them (i.e. negative impacts). The presentation of the findings is segregated into each of Moore's (2013) strategic points of value and a graphical representation as to the extent each of these SAIs report on the public value they deliver through these three main reports.

\section{Method}

\subsection{Strategic Plan to Deliver Public Value}

As noted, the key measures of SAIs' public value are ensuring public sector accountability and independently and objectively supporting reform. More commonly, SAIs publish a count of the number of reports tabled with Parliament (or the appropriate body), or report the number of completed audits in their annual report and their timeliness (e.g. Bangladesh, Canada, Hungary, UK), as well as the number of unqualified reports issued (e.g. New Zealand, Turkey). SAIs also comment that the quality of the sector's underlying financial reports has improved (e.g. Estonia), showing the impact of audit.

Audit reports are not the only means by which audit messages are communicated, with for example, the US GAO discussing in detail the number of Congressional committees it has reported to in its mission to reduce "fragmentation, overlap and duplication" in the public sector. ${ }^{15}$ Their annual report highlights recommendations it has made to improve efficiency and effectiveness. It also monitors the progress of agencies in addressing issues it has raised (as do, for example: Estonia, Iceland, New Zealand, Switzerland, Turkey).

In the $\mathrm{UK}$, the NAO is responsible for ensuring that government bodies are accountable for their economy, efficiency and effectiveness. Thus, the NAO reports that it saves taxpayers millions of pounds a year, ${ }^{16}$ possibly leading to lower government spending, lower tax rates and/or lower government deficits (Blume \& Voigt, 2011; Pollitt \&

\footnotetext{
152015 Annual Report: Additional opportunities to reduce fragmentation, overlap, and duplication and achieve other benefits. United States Government Accountability Office. Downloaded from http://www.gao.gov/about/paststratplanning.html

16 Strategy 2015-16 to 2017-18, UK National Audit Office. Downloaded from: https://www.nao.org.uk/wp-content/uploads/2015/12/NAO-Strategy-2016-17-to-2018-19-final.pdf.
} 
Summa, 1997; Talbot \& Wiggan, 2010). ${ }^{17}$ In respect of performance audits, the NAO values: (i) financial savings from efficiency improvements and waste minimisation; (ii) non-financial savings such as reduced waiting times or greater outputs; and (iii) qualitative aspects such as better planning or objective setting (Talbot \& Wiggan, 2010). ${ }^{18}$ The US' GAO also measures savings ${ }^{15}$ and, while Bangladesh SAI's annual report notes "the deterrent effect of audit is very significant that cannot be quantified", it does list the dollar value of financial settlements following audits. In addition to strengthening government they "developed a networking relationship with other watchdog agencies". ${ }^{19}$

In addition, a number of SAIs obtain feedback from their auditees, including Audit Committee Chairs and Directors (e.g. of Crown Corporations) (e.g. Australia, Canada, Estonia, Ireland, UK). Feedback includes that independently gathered on the professionalism and knowledge of staff, and the value the SAI has added. The necessity for such feedback has been noted by Morin (2001, 2008, 2014), Etverk (2002), Bowerman and Hawksmith (1999) and Vanlandingham (2011).

In highlighting the need to ensure taxpayers' funds are well spent, and that public value is delivered, Jamaica's SAI states "society needs to be aware of the negative impact arising from the lack of transparency and accountability in the public sector". ${ }^{20}$ Barrett (1996) (then the Australian auditor-general) recommends that SAIs should also monitor costs they impose on other entities.

In meeting its mission to: "support the development of Estonia [by audits] aimed at solving and preventing serious problems in society", the Estonian SAI notes "the work of the National Audit Office is aimed at the general public, Riigikogu [Parliament],

17 Scott (2003) notes that Australia does not measure such savings, due to concerns about the calculation methodology. However, Azuma (2004, p. 72) provides evidence that the ANAO reported the "ratio of financial benefits from performance audit products, including savings, compared to the full cost of outputs" as 10:1 in the financial year ended 2002, and that the United States' GAO also reports "profits and savings achieved thanks to the GAO's findings and recommendations" (p.95). Nevertheless, Talbot and Wiggan (2010) note that the NAO is unusual in valuing benefits in dollar terms. (See also Chapter 3.) (The US ability to litigate against fraud and waste may also help in quantifying audit impact there - Moor and Gates, 1987).

18 Dunleavy et al. (2009) notes that as part of its legitimacy for performance audits, the NAO is expected to achieve savings of at least 9 times greater than its costs.

19 Annual Report 2014, Office of the Comptroller and Auditor General of Bangladesh. Downloaded from http://www.cagbd.org/publication/AnnualReport2014.pdf

20 Annual Report 2015, Auditor General Department of Jamaica. Downloaded from: http://www.auditorgeneral.gov.jm/files/u5/AuGD_ANNUAL_REPORT_2015.pdf. 
central government and local authorities". ${ }^{21}$ Thus, the Estonian SAI further notes its desire to report to "people in their own language, and not in the language of officials, what the state is doing with their money and whether or not people are getting what has been promised to them for their money". ${ }^{21}$ This confirms the comment by Gendron et al. (2001), that the public remains concerned about a lack of probity and mismanagement, such as SAIs highlight in 'regular' audit reports, showing the public values SAIs' accountability role.

In respect of independently and objectively supporting reform, Estonia organises seminars and other activities to support its work in the public sector, further cementing its reputation. In addition, New Zealand notes the challenges the public sector faces in moving to new financial reporting standards, and the assistance it provides. ${ }^{22}$ Persuasiveness is seen to be important to bring about change within the public sector (Hungary), but there is a need to maintain independence (Australia) (as also noted by Noussi, 2012). Assisting the public sector with benchmarking is a tactic used by many (e.g. Hungary, New Zealand, UK).

As noted in the literature review, international collaboration is also an important part of independently and objectively supporting reform as public value. This factor is highlighted by almost every SAI; including training, conferences, utilising international standards and peer audits in order to (as the Australians note): "apply insights from other jurisdictions ... and lead and influence technical excellence in public sector audit". ${ }^{23}$ Further, the UK's SAI states: "We are the appointed external auditor of several multilateral international organisations and provide technical and managerial advice to a wide range of Supreme Audit Institutions and public accounts committees ... contributing to the development of international standards in public sector audit and accountancy". ${ }^{24}$

21 Strategy 2014-2020, Estonia National Audit Office (Riigikontroll). Downloaded from: http://www.riigikontroll.ee/Riigikontrollkuiasutus/Strateegia/tabid/140/language/enUS/Default.aspx.

22 Annual Plan 2015/16. Controller and Auditor General New Zealand. Downloaded from: http://www.oag.govt.nz/2015/annual-plan.

23 ANAO 2015-19 Corporate Plan, Australian National Audit Office. Downloaded from: http://www.anao.gov.au/About-Us/ /media/Uploads/Corporate\%20Publications/ANAO-CorporatePlan.pdf

24 Annual Report and Accounts 2014 -15, UK National Audit Office. Downloaded from: https://www.nao.org.uk/report/nao-annual-report-and-accounts-2014-15/. 


\subsection{Legitimacy and Support}

SAIs need support and legitimacy, to meet the public value strategy to strengthen (or attain) accountability and transparency in public financial management (e.g. Australia, Bangladesh, Canada, Poland, Turkey, UK). All note their need for independence. For some, the annual report was a place to call for further resources, the need to have control of those resources (e.g. Ireland, Jamaica), note work challenges arising from governmental changes (e.g. Australia, UK), and fiscal challenges due to non-payment of debts (South Africa).

Many SAIs publish a budget in their call for support. ${ }^{25}$ Accordingly, financial sustainability is one measure of support, with the South Africa SAI measuring its net surplus over time, as well as debtors' and creditors' days. ${ }^{26}$ To ensure legitimacy, SAIs aim for a clean audit report (e.g. Hungary, South Africa) and a number of SAIs have had peer reviews (e.g. Bangladesh, Canada, Poland), with Australia discussing the operation of its Audit Committee. In addition, Dankó (2014) notes that the independence of the State Audit Office of Hungary has been strengthened by a new Fundamental Law. The Turkish SAI notes: "having a reputation of being an objective and credible entity" is important. ${ }^{27}$

Core to legitimacy and support is building trust (INTOSAI, 2013; Moore, 2013). To ensure that its audits are of high quality, Jamaica's SAI obtains views of key stakeholders from focus groups during the planning and fieldwork stage of all performance audits. ${ }^{20}$ This is similar to the approach of Poland's SAI which, during 2012, convened 18 panels of experts to provide advice during and after audits (but before the audit report was published). ${ }^{28}$ Australia's SAI convenes a special (internal) committee when issues are contentious, to ensure that all matters are appropriately

25 The OECD (2014) report on Chile notes that the lack of financial autonomy is a danger threatening independence. The INTOSAI IDI report (2014) notes that, while 55\% of SAIs are able to appeal their budget allocations to the legislature, $40 \%$ report that the executive interferes in the budget process.

26 Strategic plan and budget of the Auditor-General of South Africa for 2012-2015. Downloaded from: http://www.agsa.co.za/Documents/AGSAreports/Budgetandstrategicplans/tabid/94/id/13/Default.as px.

272014 Accountability Report, Turkish Court of Audit. Downloaded from: http://www.sayistay.gov.tr/En/Upload/files/2014_Accountability\%20Report.pdf.

28 Annual Report 2013, Supreme Audit Office of the Republic of Poland. Downloaded from: https://www.nik.gov.pl/plik/id,5600.pdf 
considered (McPhee, 2012), while New Zealand's SAI obtains an independent review of its auditor appointments and fee monitoring processes. ${ }^{29}$

In terms of a further indication of trust, the Bangladesh SAI notes that Transparency International Bangladesh's National Integrity System report showed they are "a better performer than any other watchdog institutions ... acts as a major deterrent against inefficiency and corrupt use of money and ... delivering on its constitutional obligations..." (p.5). ${ }^{19}$

\subsection{Operating Capacity}

The development and deployment of operating capacity should enable SAIs to deliver public value (Moore, 2013). Commonly, SAIs report they seek to ensure their audit work is of high quality, that staff are professionally trained and that they practice good internal governance (e.g. Bangladesh, Canada, South Africa, UK). Australia recognises the way that value can be compromised if the SAI fails to influence, and fails to conduct high quality audits, to monitor and analyse change. ${ }^{23}$ The Turkish SAI lists its IT capability (e.g. number of laptops, PCs and so on), presumably to make the point that they have such capacity, ${ }^{27}$ while the US' GAO undertakes an internal survey to measure its effectiveness. ${ }^{15}$

Pollitt and Summa (1997, p. 325) note that the French SAI (the Cour des Comptes) emphasises the "high qualifications and extraordinary status of its audit staff" who are magistrates with post-graduate qualifications. ${ }^{30}$ Further, the UK's NAO highlights staff's continuous training, and thus the functionality of their work (Pollitt \& Summa, 1997). In Canada, Alberta's Auditor-General accentuates the number of senior staff serving on government task forces, which is seen as an expression of confidence in the Office (Gendron et al., 2001). Australia's SAI measures leadership capacity, contemporary communication capacity, advanced information analytics capacity, and success of new models of audit delivery. ${ }^{23}$

Azuma (2004) recommends publication of corporate documents to report value. The extent of reporting will depend on the SAI's structure (INTOSAI IDI Development

29 Audit Report 2014/15, Controller and Auditor General New Zealand. Downloaded from: http://www.oag.govt.nz/2015/annual-report

30 Nevertheless, the fact that they are judges, means that audit processes can be quite different from those in SAIs modelled along Westminster or Collegiate/Board lines (Morin, 2011). 
Initiative, 2014), with Poland's SAI being obliged to report only to the Sejm of the Republic of Poland (the lower house of Parliament). ${ }^{28}$ Further, the Swiss SAI has not reported publicly in the past, but its reports are increasingly being made available under the Freedom of Information Act and, from 2015, it plans to be even more transparent. ${ }^{31}$ Their Auditor General notes that the unintended consequences of more widelyavailable reports is a loss of confidence in government, especially when matters for improvement are highlighted.

Through the strategic plans, annual plans, budgets and annual reports published by SAIs we observe objectives (outcomes), management performance indicators and targets, linkages of outputs to outcomes (and intermediate outcomes), and how SAIs measured these. ${ }^{32}$ In this research, of the 16 countries found to have reports, 12 published a Strategic Plan covering the year 2015 (of which two were out of date) - these can be a key means to consult with relevant stakeholders. All SAIs published an Annual Report, but only five published a recent Annual/Corporate Plan to show where audit effort would be applied. Of the Annual Reports, seven included the SAI's financial statements (all of which were audited). The other annual reports included only summaries of activities (in the case of Ireland, only the financial statements were published in the annual report, with no other information).

Further measures of leading by example are provided by Gendron et al. (2001) who analysed how the Auditor General of Alberta highlights the speed with which it completes its annual report, ${ }^{33}$ how many of its recommendations are accepted by government, the costs of audits and number of recommendations in each. From the Netherlands, Lonsdale (2000) notes the SAI monitors and reports whether their work has been mentioned in the Budget Bill, whether its auditors are invited to present a

312014 Annual Report, Swiss Federal Audit Office. Downloaded from:

http://www.efk.admin.ch/images/stories/efk_dokumente/publikationen/jahresberichte/2014/CDF_ac t_2014_en_PDF.pdf.

32 In Australia and Canada cases the outcomes sought are similar: to improve the administrative management of the federal government; and to ensure the accountability of the federal government, while New Zealand's were: to maintain the integrity of financial and non-financial performance reports, to promote the better use of public resources and to make lawful payments from public funds. The United States' GAO's strategic goals included accountability of federal government, but also sought to enable government to respond to challenges of global interdependence and those associated with the well-being and financial security of Americans (Azuma, 2004).

33 In 2009 the Open Budget Survey noted that only 15 SAIs released their annual report within six months (Ramkumar, 2009) and in 2015, when the IBP (2015) reduced the time from 24 months to 12 , fewer SAIs reached that benchmark (66 instead of 68). Nevertheless, the OECD (2000, p. 64) notes "the majority of OECD countries publish the external audit reports routinely". 
report to a Standing Committee, and whether Members of Parliament (MPs) press ministries to take the recommended actions.

Reporting on costs and activity is evident in Pollitt and Summa's (1997) study of the UK, Swedish and Finnish SAI's reports. Further, Pollitt and Summa (1997, p. 317) note that the UK's NAO not only reports that its costs per audit have decreased, ${ }^{34}$ but that it also "undertakes internal quality reviews of its work using independent quality panels and surveys of audited bodies to seek their opinions of the usefulness of NAO activity".

Being responsive and communicating effectively is another measure of operating capacity. An example is provided by Canada's SAI, which has a strategic objective to ensure that users and managers find audit reports understandable, fair and add value.

In addition, Norway's SAI notes “auditing shall have great social relevance and topical merit" 35 and, for Ireland, "support effective democracy". ${ }^{36}$ Yet, the Turkish SAI notes as a weakness: "unsatisfactory relationships with external stakeholders and media". ${ }^{27}$ Thus, Hungary makes use of "citizens' indications, complaints and the issues, topics relevant to the National Assembly and the general public" in organising its work (Dankó, 2014).

To show their relevance to citizens, some SAIs report the number of press releases, others' publications that include their work and/or visits to their website (e.g. Iceland, Poland). Jamaica's SAI also logs correspondence sent and Parliamentary discussions, with South Africa logging a rather general number of "stakeholder engagements". Further, the Effective Institutions Platform (2014) provides an example of Chile's SAI's web portal that counts the number of complaints and suggestions by citizens, how they have been dealt with, the length of time to respond, and the status of any audit actions occurring as a consequence.

These examples from different SAIs' reports are summarised in Table 3 which further extends Table 1.

34 This may not be a good thing of course, especially if it impairs the achievement of objectives.

35 Strategy 2014-2018, Auditor General of Norway. Downloaded from: https://www.riksrevisjonen.no/en/AboutRR/Publications/StrategicPlan/Pages/Strategicplan.aspx.

36 Office of the Comptroller and Auditor General -Statement of Strategy 2012-2014. Ireland. Downloaded from: http://www.audgen.gov.ie/viewdoc.asp?DocID=1352. 
Table 3: Measurements of value by SAIs in this study

\begin{tabular}{|c|c|c|}
\hline $\begin{array}{l}\text { Moore's } \\
\text { strategy }\end{array}$ & $\begin{array}{l}\text { ISSAI principle/s and } \\
\text { description }\end{array}$ & Positive Impact measured by: \\
\hline \multirow[b]{2}{*}{ 1. Public Value } & $\begin{array}{l}\text { Ensuring public sector } \\
\text { accountability }\end{array}$ & $\begin{array}{l}\text { (1) Strategic plans to ensure public sector accountability; } \\
\text { (2) Dollar value of funds saved due to audits; } \\
\text { (3) Developing networking relationships with other agencies; } \\
\text { (4) None report on raising Parliamentary oversight body competency. }\end{array}$ \\
\hline & $\begin{array}{l}\text { Independently \& } \\
\text { objectively support } \\
\text { reform }\end{array}$ & $\begin{array}{l}\text { (1) Number of completed audits and timeliness, number of unqualified reports issued; } \\
\text { (2) Reporting that quality of underlying reports have improved. Benchmarking services to public sector; } \\
\text { (3) Number of reports tabled with Parliament (or appropriate body), recommendations made to improve efficiency } \\
\text { and effectiveness; } \\
\text { (4) Feedback from auditees; } \\
\text { (5) Better practice guides, contribute to Bills; } \\
\text { (6) Report overseas influence and input. }\end{array}$ \\
\hline \multirow{2}{*}{$\begin{array}{l}\text { 2. Legitimacy } \\
\text { and Support }\end{array}$} & SAI Independence & $\begin{array}{l}\text { All assert they are independent and have appropriate legislative authority, but call for more resources, and as being } \\
\text { stretched. }\end{array}$ \\
\hline & Building trust & $\begin{array}{l}\text { (1) Peer reviews, Audit Committee, Report on Integrity; } \\
\text { (2) For performance reports, using focus groups, Panel of Experts; } \\
\text { (3) Independent review of outsourced auditing. }\end{array}$ \\
\hline \multirow{2}{*}{$\begin{array}{l}\text { 3. Operating } \\
\text { Capacity }\end{array}$} & Lead by example & $\begin{array}{l}\text { (1) Reports include annual reports (16), annual plan (5) \& strategic plans (12); } \\
\text { (2) Budgets published; } \\
\text { (3) Clean audit reports on SAI's annual report are published; } \\
\text { (4) Quality of staff; } \\
\text { (5) Quality of governance; } \\
\text { (6) Environmental strategy and results of sustainability programme. }\end{array}$ \\
\hline & $\begin{array}{l}\text { Responsive-ness and } \\
\text { voice }\end{array}$ & $\begin{array}{l}\text { (1) Strategic objective to ensure that users and managers find audit reports understandable to support democracy; } \\
\text { (2) Recognise the digital era and drive to transform services; } \\
\text { (3) Citizens' complaints directs work; } \\
\text { (4) Count press releases, website visits, correspondence. }\end{array}$ \\
\hline
\end{tabular}




\section{Discussion and Conclusions}

This paper has argued (along with Raudla et al., 2015) that it is important for SAIs to report on the public value they deliver. We have used Moore's (2013) concept of public value to develop a framework of public value for SAIs and also utilised a number of SAIs' reports to observe how they report on their public value. Key to Moore's (2013) concept is that public value is defined as a collective, rather than individual measure, and thus requires more than one measure if it is to meet different stakeholders' needs. Further, Moore (2013, p. 104) notes: “...public value is conditional on the support of the political authorizing environment that has the right and responsibility to define public value ....". This reminds us that it is necessary to manage, measure and report public value, along with an SAI's legitimacy and support and operational capacity. These three strategic points are shown in Figure 1, and are discussed further in this section.

Figure 1: Graph of total scores on Public Value

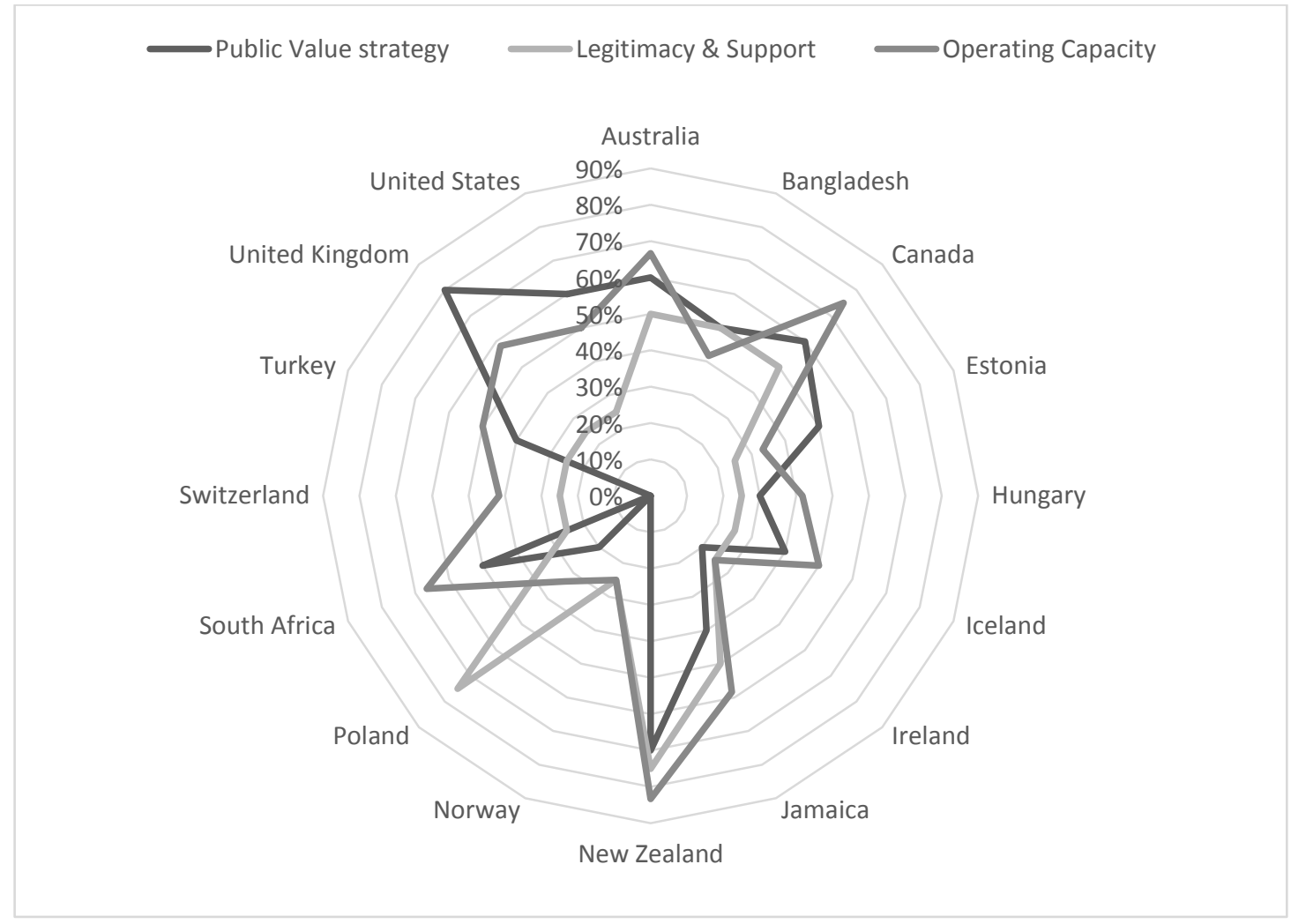

Note: percentage scores represent the number of items out of those in Table 3 under each heading reported for each country. 


\subsection{Public value in SAI reporting}

The strategic triangle points to the ability to deliver public value. This ability is twofold: ensuring public sector accountability and independently and objectively supporting public sector reform.

As can be seen in Figure 1, many SAIs have a strategic plan to ensure public sector accountability, which assists them in managing public sector risk. ${ }^{37}$ As noted by Noussi (2012) and Pallot (2003), SAIs are expected to deliver a wider, constitutional accountability. This requires the SAI to report on whether agencies in the public sector (and government itself) have exercised probity and legality in their collection and spending of citizens' (taxpayers') dollars (Friedberg \& Lutrin, 2005). In addition, the UK and US emphasise the public benefits that they deliver by providing the dollar value of funds saved through audits; further, a number of SAIs report on how many recommendations they make. Yet, our research shows that few SAIs explicitly discuss value, and of those that do, not all produce annual reports, and fewer publish annual and strategic plans.

In addition, although Parliament must be technically capable to manage the information for accountability (Reichborn-Kjennerud \& Johnsen, 2015; Santiso, 2015), none of the SAIs in this research reported publicly on how they assist Parliamentary bodies to improve their technical capacity in order to carry out their oversight roles. One explanation for this might be because, under the insurance hypothesis for audit (Hay et al., 2016), Parliament may wish the auditor to act as a scapegoat for an entity's management's failures and it suits the Public Accounts Committee not to shoulder the blame for such failures; although the omission might simply be because the SAIs were not asked to provide this service.

Many SAIs also recognise the second major public value they can bring, by independently and objectively supporting reform (Blume \& Voigt, 2011). By (i) listing the number of audits undertaken, timeliness and lack of qualifications in these audits, they provide support for the agency theory reasons for audit and (ii) by showing that

37 Out of the 10 possible items they could have reported as part of their strategic plans to deliver these public values (see table 3), the UK scored $80 \%$, New Zealand, $70 \%$ and at $60 \%$ was Australia, the US and Canada. Estonia and South Africa scored 50\%. 
public sector managers are reporting well to boards/governors, ministers, and the public, they confirm a monitoring role. Indeed, by reporting that the quality of this reporting has improved and by benchmarking outputs and outcomes, SAIs signal the quality of management. However, while most SAIs in this research listed/counted the number of audit reports they produced, fewer linked measures of outputs to the outcomes they aimed for. Some listed the benchmarking services they had developed and how accounting had improved, but such information was sparse.

The quality of the SAIs is also shown by feedback from auditees which we found a number of SAIs reporting. Yet, SAIs are reticent to critique policy (Barzelay, 1997; Czasche-Meseke, 1995; Gendron et al., 2001; Grasso \& Sharkansky, 2001; Jantz et al., 2015) and to realise the public benefits that Schelker and Eichenberger (2010) argue for. This suggests that SAIs should do more to report their outcomes and the outputs they deliver to achieve public values.

In respect of the manner in which audit can lead to organisational control, SAIs do not report on how they have undertaken internal audits (if any) or encouraged audit committees/good governance. However, organisational control is evident through SAIs' performance audits and reporting on auditees' acceptance of recommendations to improve efficiency and effectiveness ("independently and objectively supporting reform"). Yet, this measure fails to take into account negative consequences of the audit process (Leeuw, 2011), such as costs, or the manner in which requiring strict adherence to rules can reduce organisational learning. Nevertheless, most reported a range of outputs, (including education activities undertaken), however few acknowledged the fact that not all changes could be attributed to the SAI, but were as a result of collaborative and others' efforts. Attestation of these achievements is a challenge, but SAIs should lead the way in showing the public sector how to do this.

In supporting reform, SAIs also report on their influence internationally and the overseas examples that they have adopted. These recognise the positive (possible) externalities of SAIs, but the extent to which stakeholders are interested in this, is unknown. It is likely that the international experience will feed into an SAI's deliver of public benefit. 
The confirmation hypothesis notes the value of ex post audit in providing assurance to stakeholders about ex ante and other unaudited information (Hay et al., 2016). While independence is essential for this, no SAIs were observed to make a specific subsequent report on unaudited results from public sector agencies and we do not therefore have evidence of the importance of audit in giving credence to these unaudited results. However, these reports could be subsumed in routine audit reports. The public value of subsequent confirmation of unaudited announcements is worthy of further research.

\subsection{Arbiters of public value}

SAIs are unable to support reform if they do not maintain legitimacy and support. Independence is the prime means through which they do this - through the freedom SAIs have to make enquiries, call public entities to account, report, encourage change, and appoint staff (Grasso \& Sharkansky, 2001; Norton \& Smith, 2008; Schelker, 2008). Yet a number of SAIs in this study commented on budget constraints and being stretched due to extra work. Unless an appropriate level of resources is committed to these SAIs, they will be unable to undertake their core work at a high-enough quality to deliver public value. ${ }^{38}$

External reports of SAIs' legitimacy is rare, but peer reviews are one option to show external stakeholders that an SAI has legitimacy. SAIs reported on internal checks and balances for their performance audits and how they had utilised focus groups, panels of experts, and so on. Yet, New Zealand is the only SAI in our sample that reported having its own audit committee. New Zealand also obtains an independent review of its audit outsourcing. Such activities also signal audit quality.

As noted, Moore (2013) highlights the need for operating capacity. This is reflected in high quality audit work, high quality staff, and reporting (Azuma, 2004; Gendron et al., 2001; Talbot \& Wiggan, 2010). Not all SAIs in this research published their financial data openly, although those that did, included audit reports. ${ }^{39}$ This aspect of operational capacity underpins public value (by signalling quality, but also through robustness of audit) and builds legitimacy.

\footnotetext{
38 This item was scored out of a possible 4 (see table 3 for items) and Poland and New Zealand scored $3 / 4(75 \%)$. Australia, Bangladesh, Canada and Jamaica scored 50\%.

39 This item was scored out of a possible 12 (see table 3 for items). New Zealand scored $83 \%$ and Canada 75\% with Australia and South Africa scoring 67\%. Jamaica and the UK scored 58\% and Iceland, Turkey and the US scored $50 \%$.
} 
Public value cannot be delivered without each of Moore's (2013) three strategic points and learning at each point to create public value. He further notes that different stakeholders will impact these strategic points with different intensities. While all citizens will contribute to an SAI's legitimacy and support (through trust in the system and through funding), they are unlikely to contribute directly to its operational capacity. Citizens and voters are most likely to act as arbiters of public value through their voice and votes. Parliament also contributes to an SAI's legitimacy and support, as well as its operational capacity (through funding). Co-producers of the SAI (for example where audits have been outsourced, but also contributors such as professional staff etc.) also contribute to its operating capacity, and auditees (as clients) also having a moderately strong contribution. Thus, SAIs must analyse the public value they deliver from the point of view of these stakeholders.

While engagement with key stakeholders is important, our study shows that not all SAIs prioritise this (for example, Ireland's SAI posted only one press release per 12-month period on its website). With the increase in performance audits, a number of the SAIs in this research have mechanisms through which citizens can make complaints and/or suggest items for SAI enquiries (as also seen in IBS, 2015; Ramkumar, 2009). Moore (2013) argues that when public sector entities (like SAIs) attend to the public value that citizens, voters and taxpayers want, they will also be encouraged to engage the public through broader programmes, in co-producing outcomes. Therefore, research which analyses SAIs' two-way communication would show how the public engages with SIAs worldwide.

Table 1 highlighted that SAI activity may also have negative impacts, however only one SAI - the Swiss - mentioned a negative impact, namely that widely available reports may lead to a loss of confidence in government. Further, while few SAIs publish the challenges they meet in delivering public value, there is no doubt that these exist. Those that do, report the struggle for resources in order to hold the public sector accountable and to independently and objectively support reform. There is room for wider reporting and further research on other measures used in other reports, especially as one of the limitations of this research is the limited range of documents analysed and the number of SAIs in the final sample. 
As 'watchdogs of public value' (Moore \& Gates, 1987), SAIs have a responsibility to deliver and report on the public value they deliver. In undertaking empirical research to fill a gap in the literature (Bryson et al., 2016; Hartley et al., 2016), this research provides numerous examples of the ways SAIs report about the way in which they seek to increase efficiency and effectiveness in the public sector. Although de Jong et al. (de Jong et al., 2016) suggest questions about public value are rarely asked, it is evident that SAIs do report on their role in discharging such value. However, there is no evidence to suggest that SAIs are able to use their independence to critique and build fairness and justice in society as a deontological perception of value (Moore, 2013). Crosby et al. (2016) suggest that innovation and collaboration are necessary; further the question must be asked as to whether SAIs have a role in this value creation. Certainly performance audits of government services may be one aspect that could be reported on, but the lack of desire to enter policy debates (Barzelay, 1997; Gendron et al., 2001; Grasso \& Sharkansky, 2001; Jantz et al., 2015) is a disincentive that SAIs must overcome if they are to play a role in achieving a good and just society and enrol the public as an arbiter of value as argued for by Geuijen et al. (2016). In conclusion, the recognition of the need to be democratically accountable for efficiency and effectiveness is one aspect of the public value of SAIs. SAIs' reporting prioritises critiques to increase public sector efficiency and effectiveness, rather than government policy, and generally fail to discuss any negative consequences of their work. SAIs are encouraged to develop new ways to demonstrate their ongoing relevance. 


\section{References}

Alon, G. (2007), State Audit and the Media as the Watchdogs of Democracy - A Comparative View. Lyunim- The Periodical of the Office of the State Comptroller and Ombudsman, 61, 55-100.

Arthur, A., Rydland, L. T. and K. Amundsen (2012), The User Perspective in Performance Auditing - A Case Study of Norway. American Journal of Evaluation, Vol. 33, No. 1, pp. 44-59.

Azuma, N. (2004), Performance Measurement of Supreme Audit Institutions in 4 Anglo-Saxon Countries : Leading by Example. Government Auditing Review, Vol. 11(March), pp. 65-99.

Barrett, P. (1996), Some Thoughts about the Roles, Responsibilities and Future Scope of Auditors-General. Australian Journal of Public Administration, Vol. 55, No. 4, pp. 137-146.

Barrett, P. (2002). Public Sector Auditing: ANAO Approaches and Practices. Speech, Sydney, NSW: Macquarie University.

Barzelay, M. (1997), Central Audit Institutions and Performance Auditing: A Comparative Analysis of Organizational Strategies in the OECD. Governance, Vol. 10, No. 3, pp. 235-260.

Blume, L. and S. Voigt (2011), Supreme Audit Institutions: Supremely Superfluous? A Cross Country Assessment. European Journal of Political Economy, Vol. 27, No. 2, pp. 215-229.

Bowerman, M. and S. Hawksworth (1999), Local government internal auditors' perceptions of the Audit Commission. Managerial Auditing Journal, Vol. 14, No. 8, pp. 396-407.

Bowerman, M., Humphrey, C. and D. Owen. (2003), Struggling for supremacy: the case of UK public audit institutions. Critical Perspectives on Accounting, Vol. 14, pp. 1-22.

Bozeman, B. (2007), Public Values and Public Interest: Counterbalancing Economic Individualism. Washington DC: Georgetown University Press.

Bringselius, L. (2014), The Dissemination of Results from Supreme Audit Institutions: Independent Partners with the Media? Financial Accountability \& Management, Vol. 30, No. 1, pp. 75-95.

Brown, R. E. and R. Craft (1980), Auditing and public administration: the unrealized partnership. Public Administration Review, Vol. 40, No. 3, pp. 259-265.

Bryson, J. M., Crosby, B. C. and L. Bloomberg (2015), Discerning and Assessing Public Value: Major Issues and New Directions. In J. M. Bryson, B. C. Crosby, \& L. Bloomberg (Eds.), Public Value and Public Administration (pp. 1-24). 
Georgetown University Press.

Bryson, J. M., Sancino, A., Benington, J. and E. Sørensen (2016), Towards a multiactor theory of public value co-creation. Public Management Review, forthcoming.

Burgess, S. and M. Ratto (2003), The role of incentives in the public sector: Issues and evidence. Oxford Review of Economic Policy, Vol. 19, No. 2, pp. 285-300.

Chowdhury, R. R., Innes, J. and R. Kouhy (2005), The public sector audit expectations gap in Bangladesh. Managerial Auditing Journal, Vol. 20, No. 8, pp. 893-908.

Christensen, T., Lægreid, P., Roness, P. G. and K.A. Røvik (2007), Organization Theory and the Public Sector: Instrument, culture and myth. New York, NY: Routledge.

Clark, C., De Martinis, M. and M. Krambia-Kapardis (2007), Audit quality attributes of European Union supreme audit institutions. European Business Review, Vol. 19, pp. 40-71.

Crosby, B. C., Hart, P. and J. Torfing (2016), Public value creation through collaborative innovation. Public Management Review, 1(0), 1-15.

Czasche-Meseke, H. (1995), The influence of the German Federal Court of Audit ( FCA ) on policy decisions. Managerial Auditing Journal, Vol. 10, No. 9, pp. 512.

Dankó, P. (2014), Innovative initiatives at the State Audit Office of Hungary. Training event - powerpoint. Retrieved from http://www.eurosai.org/handle404?exporturi=/export/sites/eurosai/.content/docu ments/training/training-events/InSem2014/4.2.-Innovativative-initiatives.pdf

de Jong, J., Douglas, S., Sicilia, M., Radnor, Z., Noordegraaf, M. and P. Debus (2016), Instruments of value: using the analytic tools of public value theory in teaching and practice. Public Management Review, forthcoming.

Dunleavy, P., Gilson, C., Bastow, S. and J. Tinkler (2009), The National Audit Office, the Public Accounts Committee and the risk landscape in UK public policy. London, UK.

Dye, K. (2009), Working with the Media to Maximize the Impact of Your Audit Work. International Journal of Government Auditing, pp. 8-12.

Effective Institutions Platform. (2014), Supreme Audit Institutions and Stakeholder Engagement Practices: A Stocktaking Report. Geneva.

English, L. M. (2007), Performance Audit of Australian Public Private Partnerships: Legitimising Government Policies or Providing Independent Oversight? 
Financial Accountability \& Management, Vol. 23, No. 3, pp. 313-336.

Etverk, J. (2002), Measuring performance audit effectiveness: the case of Estonia. Unpublished thesis, University of Tartu.

Friedberg, A. and C. Lutrin (2005), State Audits in the United States, 1996-2000. Journal of Public Budgeting, Accounting \& Financial Management, Vol. 17, No. 1, pp. 1-32.

Funnell, W. (2015), Performance Auditing and Adjudicating Political Disputes. Financial Accountability \& Management, Vol. 31(February), pp. 92-111.

Gendron, Y., Cooper, D. J. and B. Townley (2001), In the name of accountability State auditing, independence and new public management: Accounting, Auditing \& Accountability Journal, Vol. 14, No. 3, pp. 278-310.

Geuijen, K., Moore, M., Cederquist, A., Ronning, R. and M. van Twist (2016), Creating public value in global wicked problems. Public Management Review, forthcoming

González de Aragŏn, A. (2009), Case Study: Societal Perceptions of the Superior Audit Office of Mexico. International Journal of Government Auditing, pp. 1517.

Grasso, P. G. and I. Sharkansky (2001), The Auditing of Public Policy and the Politics of Auditing: The U.S. GAO and Israel's State Comptroller. Governance, Vol. 14, No. 1, pp. 1-21.

Groenendijk, N. S. (2004), Assessing member states' management of EU finances: An empirical analysis of the annual reports of the European Court of Auditors, 1996-2001. Public Administration, Vol. 82, No. 3, pp. 701-725.

Hatherley, D. J. and L.D. Parker (1988), Performance Auditing Outcomes: A Comparative Study. Financial Accountability \& Management, Vol. 4, No. 1, pp. $21-41$.

Hartley, J., Alford, J. and O. Hughes (2015), Political Astuteness as an Aid to Discerning and Creating Public Value. In J. M. Bryson, B. C. Crosby, \& L. Bloomberg (Eds.), Public Value and Public Administration (pp. 25-38). Georgetown University Press.

Hartley, J., Alford, J., Knies, E. and S. Douglas (2016), Towards an empirical research agenda for public value theory. Public Management Review, forthcoming

Hasan, H. A., Frecknall-Hughes, J., Heald, D. and R. Hodges (2013), Auditee Perceptions of External Evaluations of the Use of Resources by Local Authorities. Financial Accountability \& Management, Vol. 29, No. 3, pp. 291326. 
Hay, D., Simpkins, K. and C.J. Cordery (2016), Investigation 1: The value of public audit. Centre for Accounting Governance and Taxation Research Working paper, Wellington, New Zealand.

International Budget Partnership. (2015), Open Budget Survey 2015. Washington DC.

International Organization of Supreme Audit Institutions. (2013), ISSAI 12: The Value and Benefits of Supreme Audit Institutions - making a difference to the lives of citizens. Copenhagen: INTOSAI.

INTOSAI IDI Development Initiative. (2014), Performance, Capacities and Needs of SAIs: Global Stocktaking Report 2014.

James, O. and P. John (2007), Public Management at the Ballot Box: Performance Information and Electoral Support for Incumbent English Local Governments. Journal of Public Administration Research and Theory, Vol. 17, No. 4, pp. 567580.

Jantz, B., Reichborn-Kjennerud, K. and K. Vrangbaek (2015), Control and Autonomy - The SAIs in Norway, Denmark and Germany as Watchdogs in an NPM-era? International Journal of Public Administration, Vol. 38, No. 13-14, pp. 960970.

Kloot, L. (2009), Performance measurement and accountability in an Australian fire service. International Journal of Public Sector Management, Vol. 22, No. 2, pp. $128-145$.

Lee, J. (2008), Preparing Performance information in the public sector: an Australian perspective. Financial Accountability \& Management, Vol. 24, No. 2, pp. 117149.

Leeuw, F. L. (2011), The Effects of Performance Audit. In J. Lonsdale, P. Wilkins, \& T. Ling (Eds.), Performance Auditing: Contributing to Accountability in Democratic Government (pp. 231-247). Cheltenham, UK: Edward Elgar Publishing Limited.

Liu, J. and B. Lin (2012), Government auditing and corruption control: Evidence from China's provincial panel data. China Journal of Accounting Research, Vol. 5, No. 2, pp. 163-186.

Lonsdale, J. (2000), Developments in Value-For-Money Audit Methods: Impacts and Implications. International Review of Administrative Sciences, Vol. 66, No. 1, pp. 73-89.

Lovell, A. (1996), Notions of Accountability and State Audit: A UK Perspective. Financial Accountability \& Management, Vol. 12, No. 4, pp. 261-280.

McPhee, I. (2012), Enhancing Audit Quality in a Supreme Audit Institution. In 5th Symposium of the Asian Organization of Supreme Audit Institutions (ASOSAI). 
Jaipur, India.

Melo, M. A., Pereira, C. and C.M. Figueiredo (2009), Political and Institutional Checks on Corruption: Explaining the Performance of Brazilian Audit Institutions. Comparative Political Studies, Vol. 42, No. 9, pp. 1217-1244.

Meynhardt, T. (2015), Public Value: Turning a Conceptual Framework into a Scorecard. In J. M. Bryson, B. C. Crosby, \& L. Bloomberg (Eds.), Public Value and Public Administration (pp. 189-203). New York, NY: Georgetown University Press.

Milgrom, T. and R. Schwartz (2008), Israel's Auditor as Policy Change Agent: The Case of Water Policy. International Journal of Public Administration, Vol. 31, No. 8, pp. 862-877.

Moore, M. H. (1995), Creating public value : strategic management in government. California, USA: Harvard University Press.

Moore, M. H. (2013), Recognizing Public Value. Cambridge \& London: Harvard University Press.

Moore, M. H. (2014), Public Value Accounting: Establishing the Philosophical Bias. Public Administration Review, Vol. 74, No. 4, pp. 465-477.

Moore, M. H. (2015), Creating a Public Value Account and Scorecard. In J. M. Bryson, B. C. Crosby, \& L. Bloomberg (Eds.), Public Value and Public Administration (pp. 110-130). Georgetown University Press.

Moore, M. H. and M.J. Gates (1987), Inspectors-General: Junkyard Dogs or Man's Best Friend? New York, NY: Russell Sage Foundation.

Morin, D. (2001), Influence of value for money audit on Public Administrations: Looking beyond appearances. Financial Accountability \& Management, Vol. 17, No. 2, pp. 99-117.

Morin, D. (2008), Auditors General's Universe Revisited. Managerial Auditing Journal, Vol. 23, No. 7, pp. 697-720.

Morin, D. (2011), Serving as magistrate at the French Cour des comptes: Navigating between tradition and modernity. Accounting, Auditing \& Accountability Journal, Vol. 24, No. 6, pp. 718-750.

Morin, D. (2014), Auditors General's impact on administrations: a pan-Canadian study (2001-2011). Managerial Auditing Journal, Vol. 29, No. 5, pp. 395-426.

Mulgan, R. (2001), Auditors-General: Cuckoos in the Managerialist Nest? Australian Journal of Public Administration, Vol. 60, No. 2, pp. 24-34.

Normanton, E. L. (1966), The Accountability and Audit of Governments. Book, Manchester: The University Press. 
Norton, S. D. and L.M. Smith (2008), Contrast and foundation of the public oversight roles of the U.S. Government Accountability Office and the U.K. National Audit Office. Public Administration Review, Vol. 68, No. 5, pp. 921-931.

Noussi, K. (2012), How Public Accountability Is Institutionalized: The case of external public auditing in global perspective - applying a mixed methods approach. Unpublished PhD Thesis, University of Vienna.

O'Leary, D. E. (2015), Armchair Auditors: Crowdsourcing Analysis of Government Expenditures. Journal of Emerging Technologies in Accounting, Vol. 12, No. 1, pp. 71-91.

OECD. (2014), Chile's Supreme Audit Institution: Enhancing Strategic Agility and Public Trust. OECD Public Governance Reviews, OECD Publishing.

Organization for Economic Cooperation and Development. (2000), Trust in Government. Ethics Measures in OECD Countries. OECD Publishing.

Organization for Economic Cooperation and Development. (2013), Trust in Government, Policy Effectiveness and the Governance Agenda. In OECD (Ed.), Government at a Glance (pp. 19-37). Geneva.

Pallot, J. (2003), A Wider Accountability? The Audit Office and New Zealand's Bureaucratic Revolution. Critical Perspectives on Accounting, Vol. 14, No. 1-2, pp. 133-155.

Pollitt, C. and H. Summa (1997), Comparative and International Administration Reflexive Watchdogs? How Supreme Audit Institutions Account for Themselves. Public Administration, Vol. 75, 313-336.

Raaum, R. B. and R.J. Campbell (2006), Challenges in Performance Auditing: How a State Auditor with Intriguing New Performance Auditing Authority is Meeting Them. Journal of Government Financial Management, Vol. 55, No. 4, pp. 2630.

Ramkumar, V. (2009), Open Budget Survey Findings on SAIs and Independence. International Journal of Government Auditing, (July), pp. 10-13.

Raudla, R., Taro, K., Agu, C. and J.W. Douglas (2015), The Impact of Performance Audit on Public Sector Organizations: The Case of Estonia. Public Organization Review, in press.

Reichborn-Kjennerud, K. and A. Johnsen, (2015), Performance Audits and Supreme Audit Institutions' Impact on Public Administration: The Case of the Office of the Auditor General in Norway. Administration and Society, early cite.

Robertson, G. (2013). Independence of Auditors General. Melbourne, Victoria, Australia. Report for the Victoria Auditors General Office. 
Santiso, C. (2015), Why budget accountability fails? The elusive links between Parliaments and audit agencies in the oversight of the budget. Brazilian Journal of Political Economy, Vol. 35, No. 3, pp. 601-621.

Schelker, M. (2008), Public Auditors : Empirical Evidence from the US States. Retrieved from http://papers.ssrn.com/sol3/papers.cfm?abstract_id=957528

Schelker, M. and R. Eichenberger (2010), Auditors and fiscal policy: Empirical evidence on a little big institution. Journal of Comparative Economics, Vol. 38, No. 4, pp. 357-380.

Schultz, D. E. J. and R.E. Brown (2003), Performance auditing in Ohio : A customer service orientation. The Journal of Government Financial Management, Vol. 52, No. 2, pp. 58-63.

Scott, C. (2003), Speaking Softly Without Big Sticks: Meta-Regulation and Public Sector Audit. Law and Policy, Vol. 25, No. (3), 203-219.

Scott, G., Bushnell, P. and N. Sallee (1990), Reform of the Core Public Sector: New Zealand Experience. Governance, Vol. 3, No. 2, pp. 138-167.

Streim, H. (1994), Agency Problems in the Legal Political System and Supreme Auditing Institution. European Journal of Law and Economics, Vol. 1, pp. 177191.

Talbot, C. and J. Wiggan (2010), The public value of the National Audit Office. International Journal of Public Sector Management, Vol. 23, No. 1, pp. 54-70.

The World Bank. (2001), Features and functions of supreme audit institutions. from the Development Economics Vice Presidency and Poverty Reduction and Economic Management Network. Retrieved from http://siteresources.worldbvank.org/INTLAWJUSTINST/Resources/premnote59. pdf.

United Nations Department of Economic and Social Affairs. (2013), Citizen Engagement Practices by Supreme Audit Institutions Citizen Engagement Practices by Supreme Audit Institutions. New York NY.: United Nations.

Van Der Meer, F. B. (1999), Evaluation and the Social Construction of Impacts. Evaluation, Vol. 5, No. 4, pp. 387-406.

Van Loocke, E. and V. Put (2011), The impact of performance audits of SAIs: a review of the existing evidence. In J. Lonsdale, P. Wilkins, \& T. Ling (Eds.), Performance Auditing: Contributing to Accountability in Democratic Government (pp. 175-208). Cheltenham, UK: Edward Elgar Publishing Limited.

Vanlandingham, G. R. (2011), Escaping the Dusty Shelf: Legislative Evaluation Offices' Efforts to Promote Utilization. American Journal of Evaluation, Vol. 32, No. 1, pp. 85-97. 
Wilkins, P. (1995), Performing Auditors?: Assessing and reporting the performance of national audit offices - a three country comparison. Australian Journal of Public Administration, Vol. 54, No. 4, pp. 421-430. 